\title{
Sistem Penghitung Jumlah Pengunjung Restoran Menggunakan Kamera Berbasis Single Shot Detector (Ssd)
}

\author{
Yosia Pradeska Admaja ${ }^{1)}$ Heri Pratikno ${ }^{2)}$ Weny Indah Kusumawati ${ }^{3)}$ \\ ${ }^{1}$ Program Studi/Jurusan Teknik Komputer, Universitas Dinamika \\ ${ }^{2}$ Jl. Raya Kedung Baruk 98 Surabaya, 60298 \\ Email:17410200022@dinamika.ac.id, heri@dinamika.ac.id,weny@dinamika.ac.id
}

\begin{abstract}
Abstrak: Wabah pandemi virus Covid-19 pada awal tahun 2020 menuntut seluruh lapisan masyarakat dan pemerintah untuk menerapkan pola hidup new normal demi mencegah penyebaran virus yang semakin meluas. Langkah pencegahan yang dilakukan pemerintah adalah melalui sosialisasi pola hidup new normal, yaitu: mewajibkan masyarakat selalu mencuci tangan, wajib menggunakan masker, mengurangi mobilitas, menjaga jarak aman kira-kira 1 meter, serta membatasi jumlah pengunjung pada pusat perbelanjaan dan pusat keramaian, seperti restoran. Bedasarkan level PPKM-nya dilakukan pembatasan jumlah pengunjung dan kapasitas maksimal orang dalam suatu ruangan. Dalam upaya pencegahan virus Covid-19 tersebut, peneliti membuat sebuah sistem penghitung jumlah pengunjung yang masuk, keluar dan yang masih berada dalam suatu ruangan pada restoran. Apabila jumlah pengunjung melebihi kapasitas ruangan yang telah ditentukan maka buzzer berbunyi sebagai tanda bahwa kapasitas ruangan overload. Metode yang digunakan pada aplikasi ini adalah Single Shot Detector (SSD) dengan integrasi dataset dari MobileNet-SSD, sehingga mampu mendeteksi object manusia secara akurat. Berdasarkan hasil pengujian dari rekaman video perorangan yang telah dilakukan, tingkat akurasi deteksi untuk object berjalan adalah $100 \%$, object berjalan cepat sebesar $90 \%$, dan tingkat akurasi object berlari adalah $50 \%$. Sedangkan pada pengujian secara realtime di pintu masuk restoran, didapatkan hasil akurasi $86 \%$ untuk penghitungan jumlah pengunjung masuk, $66 \%$ untuk akurasi penghitungan jumlah pengunjung keluar, dan akurasi sebesar $79 \%$ untuk jumlah pengunjung yang masih berada di dalam ruangan restoran.
\end{abstract}

Kata Kunci: Python, Single Shot Detector (SSD), MobileNet, Covid-19, protokol kesehatan, restoran.

\begin{abstract}
The outbreak of the Covid-19 virus pandemic in early 2020 required all levels of society and the government to implement a new normal lifestyle in order to prevent the spread of the virus from spreading. Prevention measures taken by the government are through socializing the new normal lifestyle, namely: requiring people to always wash their hands, must wear masks, reduce mobility, maintain a safe distance of about 1 meter, and limit the number of visitors to shopping centers and crowd centers, such as restaurants. Based on the PPKM level, there are restrictions on the number of visitors and the maximum capacity of people in a room. In an effort to prevent the Covid-19 virus, researchers created a system to calculate the number of visitors who entered, left and who were still in a room at the restaurant. If the number of visitors exceeds the specified room capacity, the buzzer sounds as a sign that the room capacity is overloaded. The method used in this application is Single Shot Detector (SSD) with dataset integration from MobileNet-SSD, so that it is able to detect human objects accurately. Based on the test results from individual video recordings that have been carried out, the detection accuracy rate for walking objects is $100 \%$, objects run fast by $90 \%$, and the accuracy rate for running objects is $50 \%$. Meanwhile, in realtime testing at the restaurant entrance, the results obtained accuracy of $86 \%$ for calculating the number of visitors entering, $66 \%$ for the accuracy of calculating the number of visitors leaving, and an accuracy of $79 \%$ for the number of visitors who are still in the restaurant room.
\end{abstract}

Keywords: Python, Single Shot Detector (SSD), MobileNet, Covid-19, health protocols, restaurants. 


\section{PENDAHULUAN}

Pada tanggal 12 Maret 2020, WHO menyebarkan pengumuman mengenai Covid-19 sebagai pandemik. Sampai dengan tanggal 29 Maret 2020, data kematian tercatat sebanyak 33.106 dari 634.835 kasus di seluruh dunia. Sedangkan di Indonesia sendiri terdapat 1.528 kasus positif Covid-19 dan yang meninggal ada 136 kasus [1]. Covid-19 merupakan penyakit baru yang disebabkan oleh Virus Corona, perlu mendapat perhatian karena penyebarannya relatif cepat, dan memiliki angka kematian yang tidak dapat diabaikan [2].

Covid-19 merupakan penyakit yang diakibatkan virus SARS-CoV-2. Pasien Covid-19 dengan komorbid memiliki tingkat resiko lebih tinggi [3]. Faktor resiko kematian paling tinggi pada Covid-19 adalah Laki-laki, berusia lanjut, diabetes, dan hipertensi [4]. Pada penelitian lain yang membahas tentang penyakit bawaan dipaparkan bahwa ada beberapa penyakit bawaan yang berhubungan erat dengan Covid-19 yaitu: penyakit jantung, hipertensi dan diabetes mellitus, hipertensi dan diabetic ketoacidosis [5].

Sejak virus mulai menyerang Indonesia, pemerintah telah menetapkan kebijakan protokol kesehatan yang direkomendasikan oleh WHO, yaitu menyediakan berbagai fasilitas medis bagi pasien yang terinfeksi virus corona, dan menerapkan social distancing, bahkan sampai menerapkan Pembatasan Sosial Berskala Besar (PSBB) di wilayah-wilayah Indonesia, terutama daerah rawan terinfeksi virus corona [6]. Arahan PSBB tersebut mengacu pada UndangUndang Nomor 6 Tahun 2018 tentang Kekarantinaan Kesehatan, serta didukung oleh Peraturan Pemerintah tentang Pembatasan Sosial Berskala Besar (PP Nomor 21 Tahun 2020) dan Keputusan Presiden Nomor 11 Tahun 2020 tentang Kedaruratan Kesehatan [7].

Pemerintah menerapkan kebijakan pada masa dan menghimbau kepada seluruh masyarakat yang untuk patuhdan mengikuti aturan protokol kesehatan [8]. Ada 7 aturan yang harus dipatuhi pada masa new normal, yaitu: mencuci tangan, dilarang menyentuh area wajah, menutup mulut pada saat batuk dan bersin, menggunakan masker, menjaga jarak, melakukan isolasi mandiri bila terinfeksi, dan menjaga kesehatan, berjemur, makan makanan bergizi, dan berolahraga [9].

Beberapa negara termasuk Indonesia, saat ini sedang merencanakan tatanan new normal di saat pandemi Covid-19. Restoran adalah salah satu fasilitas umum yang harus dipersiapkan, karena mempunyai potensi menyebarkan penularan Covid-19 [10]. Pemilik usaha makanan atau restoran harus memperoleh kepercayaan konsumen dengan memberikan kualitas produk yang sehat, higienis, dan aman. Selain itu juga menjalankan protokol kesehatan, meningkatkan penjualan online, take away, dan delivery order, serta menciptakan ragam produk makanan sehat yang berupa frozen food [11].

Berdasarkan adanya pembatasan jumlah pengunjung yang ditetapkan oleh pemerintah Indonesia, maka pada penelitian ini membuat sebuah sistem yang mampu menghitung jumlah pengunjung pada suatu restoran, baik pengunjung yang memasuki restoran, pengunjung yang sedang di dalam restoran, maupun pengunjung yang sudah keluar dari restoran. Penelitian ini menggunakan metode Single Shot Detector (SSD) yang terintegrasi dengan dataset dari MobleNet-SSD. Integrasi tersebut mampu untuk mendeteksi object manusia dari data input yang berasal dari hasil rekaman kamera, sehingga dapat dihitung jumlah pengunjung yang masuk, keluar, dan masih berada di dalam ruangan. Hasil penghitungan ditampilkan pada layar monitor PC atau TV yang berfungsi sebagai output.

Single Shot Detector (SSD) adalah algoritma yang dapat mendeteksi objek dalam sebuah gambar atau video dan memiliki akurasi yang lebih tinggi serta memproses gambar yang ditangkap oleh kamera lebih cepat [12]. (Sik-Ho Tsang, 2018). Metode SSD memiliki tingkat akurasi yang tinggi dibandingkan dengan metode sekelasnya seperti YOLO dan RCNN. Metode ini mampu memberikan akurasi lebih akurat dari YOLO dan kecepatan pemrosesan lebih cepat dari RCNN. Kelemahan dari metode ini adalah kemampuannya masih dirasa kurang dalam mendeteksi object dengan ukuran kecil [13].

Terdapat beberapa penelitian lain yang menggunakan permasalahan penghitungan object. Salah satunya adalah "Perancangan Program Pendeteksi Dan Pengklasifikasi Jenis Kendaraan Dengan Metode Convolutional Neural Network (CNN) Deep Learning", yang membahas mengenai proses deteksi, klasifikasi, dan menghitung kendaraan menggunakan metode Convolutional Neural Network (CNN) Deep Learning dengan algoritma You Only Look Once (YOLO). Hasilnya masih memiliki kekurangan yaitu akurasi belum maksimal ketika mendeteksi object di jalan yang padat, dan belum ada fitur untuk reporting hasil proses identifikasi object kedalah bentuk file PDF atau spreadsheet [14].

Penelitian yang lain adalah "Implementation of Tensorflow In The CCTV-Based People Counter Application at PT Matahari Department Store, Tbk". Penelitian ini membahas tentang digunakan untuk menghitung keluar masuknya orang-orang di toko PT. Matahari Department Store menggunakan algoritma TensorFlow. Namun penelitian tersebut memiliki beberapa kekurangan yaitu penempatan kamera yang belum tepat, serta akurasi pengenalan object masih belum akurat, penggunaan kamera yang memliki resolusi kecil, dan belum ada fitur untuk menuliskan hasil deteksi ke dalam file dengan format lain (PDF atau spreadsheet) [15].

Untuk aplikasi dalam kehidupan yang nyata cukup sulit untuk menentukan atau membandingkan model detektor obyek mana yang terbaik antara YOLO, SSD dan Faster-RCNN. Ada beberapa faktor yang mempengaruhi kinerja dari ketiga model detektor obyek tersebut diatas, diantaranya: banyaknya fitur, resolusi citra, jumlah dataset dan data augmentation.

Pada penelitian [16] telah melakukan komparasi 6 model detektor obyek, diantaranya: YOLO, SSD dan 
Faster-RCNN dengan kesimpulan sebagi berikut: YOLO mempunyai waktu komputasi yang tercepat dari ketiga model tersebut tetapi akurasinya lebih rendah daripada SSD [17]. Faster-RCNN mempunyai akurasi tinggi tetapi mempunyai kecepatan komputasi terendah, sedangkan SSD yang digunakan pada penelitian ini mempunyai kelebihan, yaitu: keseimbangan yang baik antara kecepatan komputasi dan akurasinya, disamping itu SSD paling memungkinkan dapat berjalan pada sistem komputasi dengan kebutuhan spesifikasi perangkat keras yang paling minimalis daripada YOLO $[18,19]$ dan FasterRCNN.

Kontribusi utama dalam penelitian ini adalah memberikan solusi untuk monitoring jumlah pengunjung serta pemantauan kapasitas ruangan di suatu restoran, sehingga tidak melanggar aturan yang telah ditetapkan oleh pemerintah daerah terkait dengan pembatasan jumlah pengunjung yang diperbolehkan masuk. Selain itu penelitian menggunakan metode SSD mampu mendeteksi pengunjung restoran dengan tingkat akurasi yang tinggi.

\section{METODE}

Penelitian ini mempunyai tujuan untuk membuat sebuah sistem yang dapat menghitung jumlah pengunjung masuk, keluar, dan jumlah pengunjung yang masih berada di dalam suatu ruangan restoran.

\section{Perancangan Perangkat Keras (Hardware)}

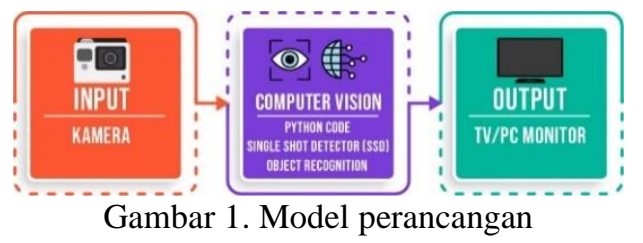

1. Input: data yang digunakan untuk pengujian aplikasi berupa hasil rekaman video dari kamera web serta proses deteksi obyek secara realtime menggunakan wireless IP Camera.

2. Computer Vision: pemrosesan video input menggunakan bahasa pemrograman python dengan penerapan metode Single Shot Detector (SSD) serta penggabungan dataset hasil proses training dari pretrained network MobileNet-SSD untuk seleksi dan penghitungan object manusia.

3. Output: Hasil pemrosesan akan ditampilkan pada layar monitor atau TV yang digunakan dengan bentuk tampilan output berupa waktu (jam, menit, detik, tanggal, bulan, tahun) serta jumlah hasil penghitungan jumlah pengunjung yang masuk, keluar, dan di dalam area restoran.

\section{Perancangan Perangkat Lunak (Software)}

Sistem diawali dengan memasukkan jumlah kapasitas maksimal dari suatu ruangan, yang kemudian ditampung pada variabel Max. Kemudian sistem berlanjut ke proses pembacaan data input hasil rekaman peneliti dan mengubah video menjadi greyscale serta memperkecil resolusi videonya dengan tujuan agar lebih mudah dalam proses analisis dan deteksi object manusia.

Setelah proses sebelumnya selesai, dilanjutkan ke proses tracking object dengan tujuan untuk mengetahui arah pergerakan object manusia, sehingga dapat ditentukan apakah object tersebut sedang berjalan masuk atau keluar. Penentuan kriteria object yang masuk adalah ketika object tersebut berjalan turun dan melewati garis batas penghitungan, untuk kriteria object yang keluar adalah ketika object tersebut berjalan naik dan melewati garis batas penghitungan.

Data jumlah object yang masuk tersimpan pada variabel Down, dan data jumlah object yang keluar akan tersimpan pada variabel $\boldsymbol{U p}$. Dari data jumlah tersebut, dapat dihitung jumlah pengunjung yang masih berada di dalam ruangan dengan cara mengurangkan jumlah variabel Down dengan jumlah variabel $\boldsymbol{U p}$.

Sistem ini juga dilengkapi dengan fitur notifikasi ketika jumlah pengunjung yang berada di dalam sudah mencapai batas maksimal sesuai yang telah ditentukan sebelumnya pada variabel Max. Notifikasi memunculkan pesan text pada layar seperti pada gambar 3 yang menandakan bahwa kapasitas sudah mencapai batas maksimal, dan alarm dari buzzer berbunyi pada saat kapasitas ruangan melebihi batas maksimal nilai yang telah di-entry pada sistem.
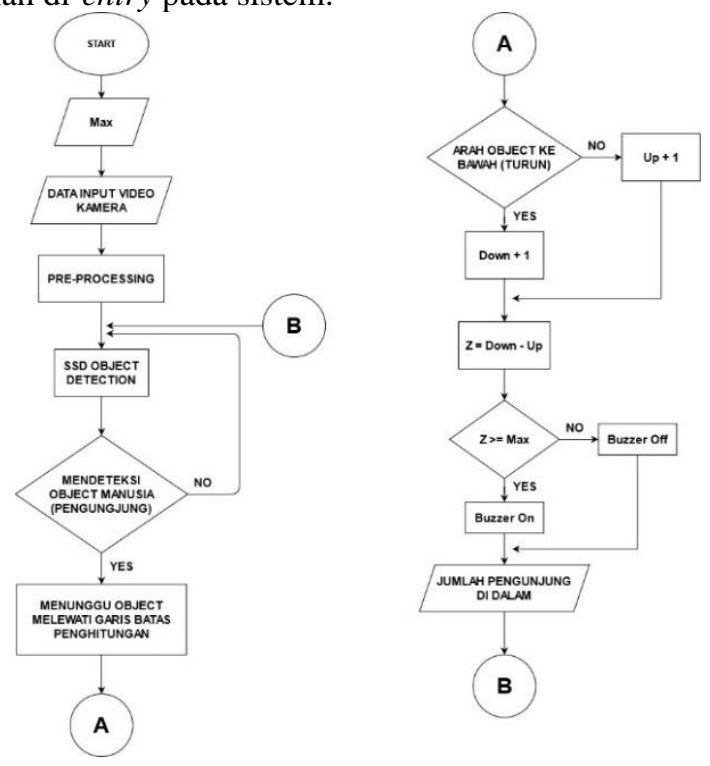

Gambar 2. Algoritma sistem

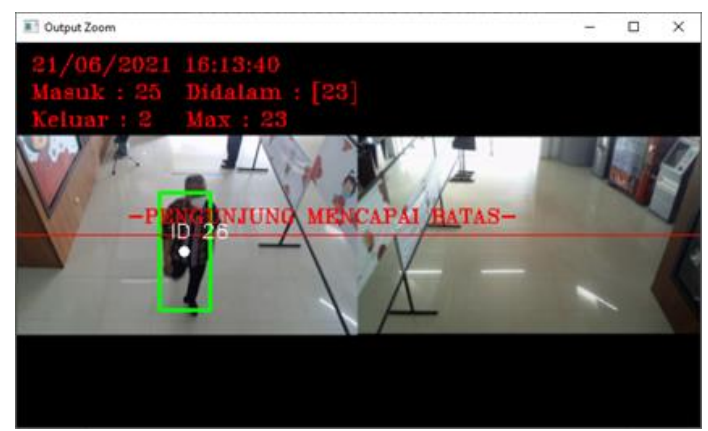

Gambar 3. Tampilan notifikasi 


\section{HASIL DAN PEMBAHASAN}

\section{Pengujian Deteksi Object}

Tujuan dari pengujian ini adalah mengetahui kemampuan sistem dalam mendeteksi seluruh object yang ada pada suatu video maupun object secara realtime. Dengan menggunakan algoritma Single Shot Detector (SSD) yang terintegrasi dengan dataset dari MobileNetSSD dapat disimpulkan bahwa nilai akurasi deteksi object ini mampu membedakan jenis object dengan akurat sesuai dengan Gambar 4 nilai akurasi deteksi object manusia adalah $100 \%$, nilai akurasi deteksi object sepeda motor adalah $100 \%$, dan nilai akurasi pada object anjing adalah $96 \%$.

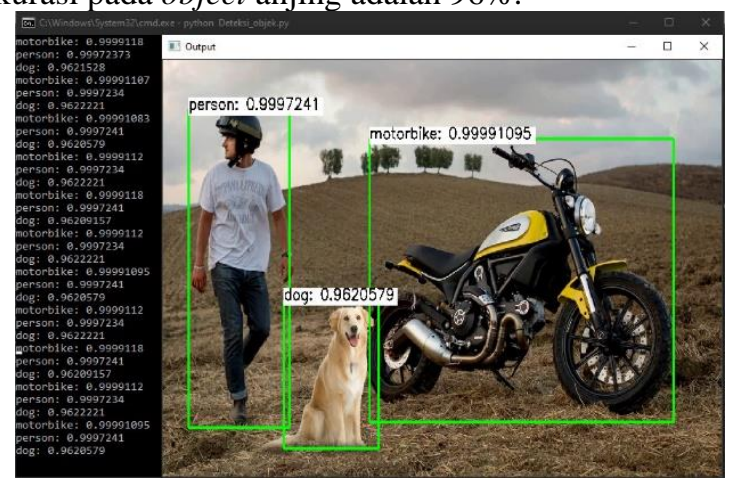

Gambar 4. Deteksi multi-object

\section{Seleksi Object Manusia}

Seleksi object manusia bertujuan untuk mempermudah proses penghitungan jumlah pengunjung, karena yang dideteksi dan dihitung adalah object manusia, sehingga nantinya tidak ada interferensi dari object lain seperti hewan atau kendaraan yang melintas. Pada Gambar 5 menandakan bahwa proses seleksi object manusia sudah berhasil dengan akurasi 100\%, sehingga object lain secara otomatis diabaikan.

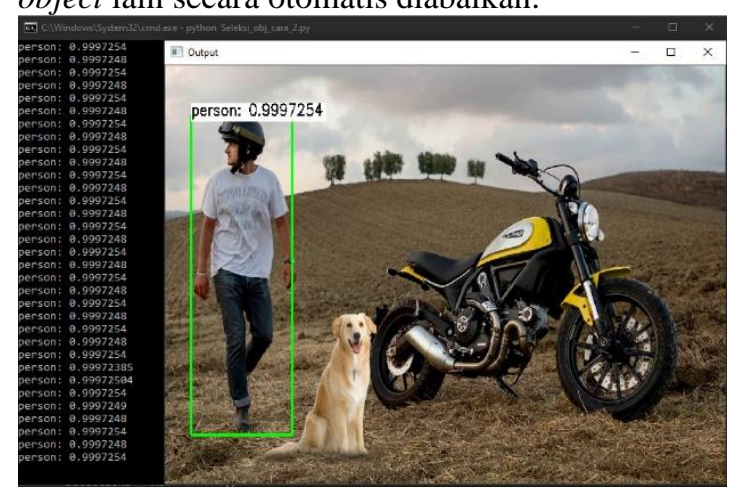

Gambar 5. Deteksi object manusia

\section{Pengujian Akurasi Person Detection}

Tujuan dari proses ini adalah untuk memastikan nilai akurasi terhadap object manusia yang berada dalam video dengan kondisi object sedang berjalan, berjalan cepat, dan berlari. Kecepatan normal orang berjalan kaki apabila tidak ada halangan sekitar $4,8 \mathrm{Km}$ per jam atau 79,25 m per menit, akan meningkat sedikit untuk lakilaki serta sebaliknya bagi perempuan. Jika jalannya menanjak atau adanya halangan, misalnya ada kerumunan orang, tanda lalu lintas dan sebagainya maka dapat memperlambat sekitar $25 \%$.

Kecepatan lari rata-rata seorang wanita adalah 10,21 per mil atau $16,428 \mathrm{Km}$ per jam, sedangkan kecepatan lari rata-rata untuk pria adalah 9,03 per mil atau sekitar 14,529 Km per jam. Sedangkan defini berjalan cepat adalah kondisi kecepatan rata-rata setengah berlari [20].

Tabel 1. Hasil pengujian akurasi person detection

\begin{tabular}{|c|c|c|c|c|c|}
\hline \multirow{2}{*}{$\begin{array}{c}\text { Data } \\
\text { Ke- }\end{array}$} & \multirow{2}{*}{$\begin{array}{l}\text { Kondisi } \\
\text { Object }\end{array}$} & \multirow{2}{*}{$\begin{array}{l}\text { Tinggi } \\
\text { Badan }\end{array}$} & \multirow{2}{*}{$\begin{array}{l}\text { Berat } \\
\text { Badan }\end{array}$} & \multicolumn{2}{|c|}{ Hasil } \\
\hline & & & & $\begin{array}{c}\text { Terdete } \\
\text { ksi }\end{array}$ & $\begin{array}{l}\text { Tid } \\
\text { ak }\end{array}$ \\
\hline 1 & $\begin{array}{c}\text { Jalan } \\
\text { Jalan cepat } \\
\text { Berlari } \\
\end{array}$ & $175 \mathrm{Cm}$ & $90 \mathrm{Kg}$ & $\begin{array}{l}\checkmark \\
\checkmark\end{array}$ & $\checkmark$ \\
\hline 2 & $\begin{array}{c}\text { Jalan } \\
\text { Jalan cepat } \\
\text { Berlari }\end{array}$ & $178 \mathrm{Cm}$ & $88 \mathrm{Kg}$ & $\checkmark$ & $\begin{array}{l}\checkmark \\
\checkmark\end{array}$ \\
\hline 3 & $\begin{array}{c}\text { Jalan } \\
\text { Jalan cepat } \\
\text { Berlari } \\
\end{array}$ & $174 \mathrm{Cm}$ & $66 \mathrm{Kg}$ & $\begin{array}{l}\checkmark \\
\checkmark \\
\checkmark \\
\end{array}$ & \\
\hline 4 & $\begin{array}{c}\text { Jalan } \\
\text { Jalan cepat } \\
\text { Berlari }\end{array}$ & $173 \mathrm{Cm}$ & $60 \mathrm{Kg}$ & $\begin{array}{l}\checkmark \\
\checkmark\end{array}$ & $\checkmark$ \\
\hline 5 & $\begin{array}{c}\text { Jalan } \\
\text { Jalan cepat } \\
\text { Berlari } \\
\end{array}$ & $155 \mathrm{Cm}$ & $88 \mathrm{Kg}$ & $\begin{array}{l}\checkmark \\
\checkmark\end{array}$ & $\checkmark$ \\
\hline 6 & $\begin{array}{c}\text { Jalan } \\
\text { Jalan cepat } \\
\text { Berlari } \\
\end{array}$ & $150 \mathrm{Cm}$ & $62 \mathrm{Kg}$ & $\begin{array}{l}\checkmark \\
\checkmark \\
\checkmark \\
\end{array}$ & \\
\hline 7 & $\begin{array}{c}\text { Jalan } \\
\text { Jalan cepat } \\
\text { Berlari }\end{array}$ & $170 \mathrm{Cm}$ & $87 \mathrm{Kg}$ & $\begin{array}{l}\checkmark \\
\checkmark\end{array}$ & $\checkmark$ \\
\hline 8 & $\begin{array}{c}\text { Jalan } \\
\text { Jalan cepat } \\
\text { Berlari } \\
\end{array}$ & $176 \mathrm{Cm}$ & $81 \mathrm{Kg}$ & $\begin{array}{l}\checkmark \\
\checkmark \\
\checkmark \\
\end{array}$ & \\
\hline 9 & $\begin{array}{c}\text { Jalan } \\
\text { Jalan cepat } \\
\text { Berlari }\end{array}$ & $173 \mathrm{Cm}$ & $69 \mathrm{Kg}$ & $\begin{array}{l}\checkmark \\
\checkmark \\
\checkmark\end{array}$ & \\
\hline & Jalan & & & $\checkmark$ & \\
\hline 10 & $\begin{array}{c}\text { Jalan cepat } \\
\text { Berlari }\end{array}$ & $172 \mathrm{Cm}$ & $64 \mathrm{Kg}$ & $\begin{array}{l}\checkmark \\
\checkmark \\
\end{array}$ & \\
\hline 11 & $\begin{array}{c}\text { Jalan } \\
\text { Jalan cepat } \\
\text { Berlari }\end{array}$ & $157 \mathrm{Cm}$ & $85 \mathrm{Kg}$ & $\begin{array}{l}\checkmark \\
\checkmark \\
\checkmark \\
\end{array}$ & \\
\hline
\end{tabular}

Dari hasil pengujian tersebut, dapat ditentukan nilai akurasi untuk setiap kondisi yaitu: berjalan, jalan cepat, dan berlari dengan menggunakan rumus (1).

$$
\text { Akurasi }=\left(\frac{\text { terdeteksi }}{\text { banyak data percobaan }} * 100 \%\right)
$$

$$
\text { Akurasi Object Berjalan }=\left(\frac{\mathbf{1 0}}{\mathbf{1 0}} * \mathbf{1 0 0} \%\right)
$$$$
=100 \%
$$

Akurasi Object Berjalan Cepat $=\left(\frac{\mathbf{9}}{\mathbf{1 0}} * \mathbf{1 0 0} \%\right)$

$$
=90 \%
$$

Akurasi Object Berlari $=\left(\frac{\mathbf{5}}{\mathbf{1 0}} * \mathbf{1 0 0} \%\right)$

$$
=50 \%
$$


Berdasarkan hasil dari Tabel 1 serta hasil perhitungan akurasi yang dilakukan menggunakan rumus (1) dapat dijelaskan sebagai berikut: untuk mendeteksi object orang dengan kondisi berjalan maka SSD dapat mendeteksi pergerakannya dengan tepat $100 \%$, sedangkan untuk proses deteksi pergerakan orang dengan kondisi berjalan cepat atau bisa dikatakan setengah berlari maka kemampuan deteksi dari metode SSD akurasinya 90\%. Adapun pada saat object berlari akurasi deteksi dari SSD turun menjadi 50\%, hal ini berarti proses deteksi object melalui bounding box pada beberapa frame telah terjadi kehilangan center point sebagai ID untuk proses seleksi dan penghitungan sehingga pergerakan dari object tidak terdeteksi maka sudah barang tentu hal ini akan berdampak pada hasil akurasinya.

\section{Pengujian Akurasi Penghitungan Jumlah Pengunjung}

Tujuan dari pengujian ini adalah untuk memastikan penghitungan dapat berfungsi dengan baik. Langkah awal adalah menghitung manual jumlah pengunjung yang masuk, keluar dan berada di dalam ruangan, kemudian membandingkan dengan hasil penghitungan dari aplikasi.

Berdasarkan hasil percobaan yang telah dilakukan secara empiris penghitungan jumlah pengunjung yang masuk maupun keluar pintu restoran yang hampir secara bersamaan masih tetap dapat dihitung dengan tepat karena pada saat obyek masuk dalam area pantuan kamera langsung secara otomatis diberi nomer ID pada titik tengah bounding box (anchor point), terkecuali para pengunjung tersebut saling berhimpitan kearah samping atau depan-belakang maka kondisi tersebut akan dihitung sebagai satu object saja.

Percobaan dilakukan dengan menghitung selisih penghitungan antara aplikasi dengan penghitungan manual, setiap percobaan dilakukan dengan durasi 1 menit dengan total akumulasi setiap menitnya dari 1 menit sampai 10 menit.

Tabel 2. Pengujian akurasi penghitungan

\begin{tabular}{|c|c|c|c|c|c|c|c|c|c|}
\hline \multirow{3}{*}{ 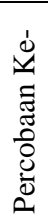 } & \multicolumn{6}{|c|}{ Hasil Penghitungan } & \multirow{2}{*}{\multicolumn{3}{|c|}{$\begin{array}{c}\text { Selisih } \\
\text { Penghitungan }\end{array}$}} \\
\hline & \multicolumn{3}{|c|}{ Aplikasi } & \multicolumn{3}{|c|}{ Manual } & & & \\
\hline & 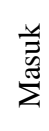 & 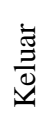 & 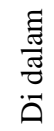 & 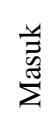 & 胥 & 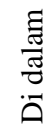 & 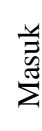 & 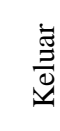 & 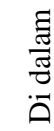 \\
\hline 1 & 7 & 1 & 6 & 8 & 1 & 7 & 1 & 0 & 1 \\
\hline 2 & 13 & 1 & 12 & 13 & 2 & 11 & 0 & 1 & 1 \\
\hline 3 & 21 & 1 & 20 & 23 & 1 & 22 & 2 & 0 & 2 \\
\hline 4 & 29 & 1 & 28 & 31 & 1 & 30 & 2 & 0 & 2 \\
\hline 5 & 36 & 3 & 33 & 38 & 3 & 35 & 2 & 0 & 2 \\
\hline 6 & 46 & 5 & 41 & 51 & 4 & 47 & 5 & 1 & 4 \\
\hline 7 & 51 & 8 & 43 & 58 & 4 & 54 & 7 & 4 & 11 \\
\hline 8 & 58 & 9 & 49 & 66 & 4 & 62 & 8 & 5 & 13 \\
\hline 9 & 62 & 9 & 53 & 71 & 5 & 66 & 9 & 4 & 13 \\
\hline 10 & 67 & 9 & 58 & 78 & 5 & 73 & 11 & 4 & 15 \\
\hline
\end{tabular}

Dari hasil pengujian yang dilakukan, masih ditemukan adanya selisih, selanjutnya adalah menghitung nilai akurasi penghitungan aplikasi menggunakan rumus (2).

$$
\begin{aligned}
& \text { Akurasi }=100 \%-\left(\frac{\text { selisih }}{\text { hitungmanual }} * 100 \%\right) \\
& =100 \%-\left(\frac{11}{78} * 100 \%\right) \\
& =100 \%-14 \% \\
& =\mathbf{8 6} \%
\end{aligned}
$$

$$
\begin{aligned}
\text { Object } \text { Keluar } & =\mathbf{1 0 0} \%-\left(\frac{\text { selisih }}{\text { hitungmanual }} * \mathbf{1 0 0} \%\right) \\
& =\mathbf{1 0 0} \%-\left(\frac{\mathbf{4}}{\mathbf{9}} * \mathbf{1 0 0} \%\right) \\
& =\mathbf{1 0 0} \%-\mathbf{4 4} \% \\
& =66 \%
\end{aligned}
$$

Object di Dalam

\begin{tabular}{|c|c|c|c|c|}
\hline \multirow{2}{*}{$\begin{array}{c}\text { Perco- } \\
\text { baan } \\
\text { Ke- }\end{array}$} & \multicolumn{2}{|c|}{ Jumlah Pengunjung } & \multicolumn{2}{|c|}{ Notifikasi } \\
\hline & $\begin{array}{c}\text { Ter- } \\
\text { deteksi }\end{array}$ & Batas Max & $\begin{array}{c}\text { Text } \\
\text { Pesan }\end{array}$ & $\begin{array}{l}\text { Suara } \\
\text { Buzzer }\end{array}$ \\
\hline 1 & 1 Orang & 1 Orang & Tampil & Aktif \\
\hline 2 & 2 Orang & 2 Orang & Tampil & Aktif \\
\hline 3 & 3 Orang & 3 Orang & Tampil & Aktif \\
\hline 4 & 4 Orang & 4 Orang & Tampil & Aktif \\
\hline 5 & 5 Orang & 5 Orang & Tampil & Aktif \\
\hline 6 & 6 Orang & 6 Orang & Tampil & Aktif \\
\hline 7 & 7 Orang & 7 Orang & Tampil & Aktif \\
\hline 8 & 8 Orang & 8 Orang & Tampil & Aktif \\
\hline 9 & 9 Orang & 9 Orang & Tampil & Aktif \\
\hline 10 & 10 Orang & 10 Orang & Tampil & Aktif \\
\hline 11 & 11 Orang & 11 Orang & Tampil & Aktif \\
\hline 12 & 12 Orang & 12 Orang & Tampil & Aktif \\
\hline 13 & 13 Orang & 13 Orang & Tampil & Aktif \\
\hline 14 & 14 Orang & 14 Orang & Tampil & Aktif \\
\hline 15 & 15 Orang & 15 Orang & Tampil & Aktif \\
\hline 16 & 16 Orang & 16 Orang & Tampil & Aktif \\
\hline 17 & 17 Orang & 17 Orang & Tampil & Aktif \\
\hline 18 & 18 Orang & 18 Orang & Tampil & Aktif \\
\hline 19 & 19 Orang & 19 Orang & Tampil & Aktif \\
\hline 20 & 20 Orang & 20 Orang & Tampil & Aktif \\
\hline 21 & 21 Orang & 21 Orang & Tampil & Aktif \\
\hline 22 & 22 Orang & 22 Orang & Tampil & Aktif \\
\hline 23 & 23 Orang & 23 Orang & Tampil & Aktif \\
\hline 24 & 24 Orang & 24 Orang & Tampil & Aktif \\
\hline 25 & 25 Orang & 25 Orang & Tampil & Aktif \\
\hline 26 & 26 Orang & 26 Orang & Tampil & Aktif \\
\hline 27 & 27 Orang & 27 Orang & Tampil & Aktif \\
\hline 28 & 28 Orang & 28 Orang & Tampil & Aktif \\
\hline 29 & 29 Orang & 29 Orang & Tampil & Aktif \\
\hline
\end{tabular}

$$
\begin{aligned}
& =100 \%-\left(\frac{\text { selisih }}{\text { hitungmanual }} * 100 \%\right) \\
& =100 \%-\left(\frac{15}{73} * 100 \%\right) \\
& =100 \%-21 \% \\
& =79 \%
\end{aligned}
$$

\section{Pengujian Notifikasi Kapasitas Maksimal}

Hasil percobaan pada Tabel 3 dapat diketahui tingkat akurasi notifikasi ketika pengunjung mencapai batas maksimal adalah $100 \%$. Nilai akurasi tersebut dihitung dengan rumus (3).

Tabel 3. Pengujian melebihi kapasitas ruangan yang telah ditentukan 


\begin{tabular}{ccccc}
\hline Perco- & \multicolumn{2}{c}{ Jumlah Pengunjung } & \multicolumn{2}{c}{ Notifikasi } \\
\cline { 2 - 5 } baan & Ter- & \multirow{2}{*}{ Batas Max } & Text & Suara \\
Ke- & deteksi & & Pesan & Buzzer \\
\hline 30 & 30 Orang & 30 Orang & Tampil & Aktif \\
\hline
\end{tabular}

$$
\begin{aligned}
\text { Akurasi } & =\left(\frac{\text { berhasil }}{\text { totalpercobaan }} * 100 \%\right) \\
= & \left(\frac{30}{30} * 100 \%\right) \\
= & 100 \%
\end{aligned}
$$

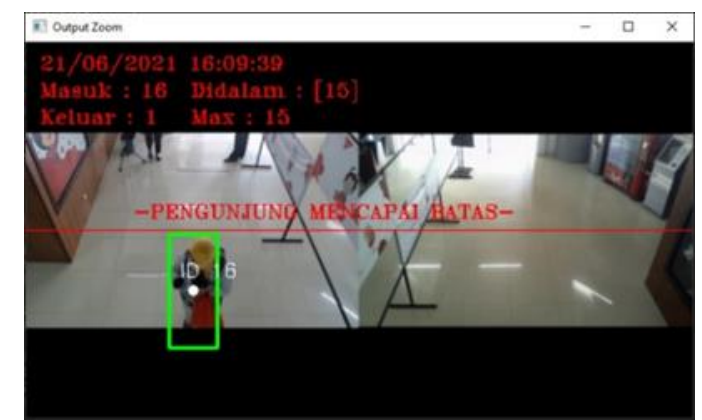

Gambar 6. Pengujian batas maksimal 15 orang

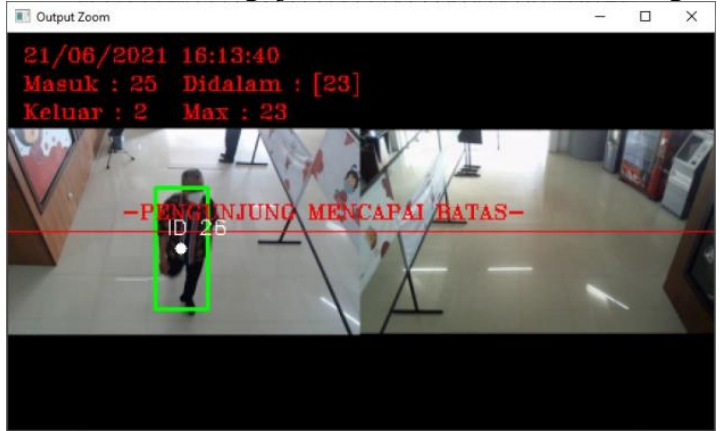

Gambar 7. Pengujian batas maksimal 23 orang

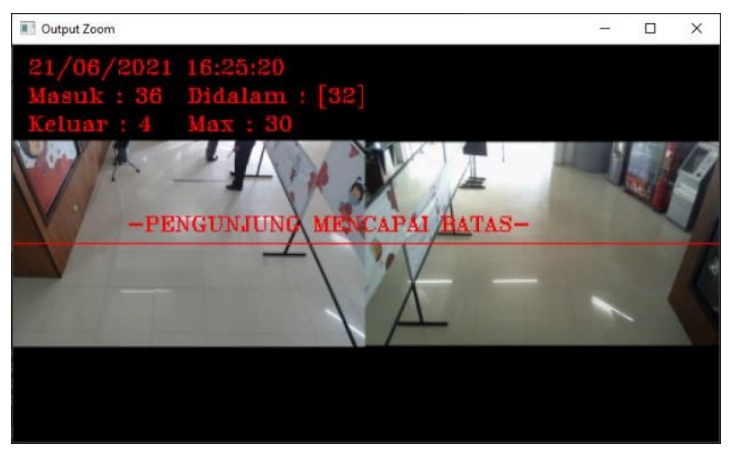

Gambar 8. Pengujian batas maksimal 30 orang

Gambar 6, gambar 7, dan gambar 8 merupakan hasil pengujian notifikasi ketika pengunjung mencapai batas maksimal.

\section{Pengujian Data Reporting}

Tujuan dari pengujian ini adalah untuk memastikan data yang tampil pada layar monitor pada waktu tertentu bernilai sama dengan hasil yang

\begin{tabular}{|c|c|c|c|c|c|c|}
\hline \multirow{2}{*}{ 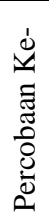 } & \multicolumn{3}{|c|}{$\begin{array}{c}\text { Penghitungan } \\
\text { Aplikasi }\end{array}$} & \multicolumn{3}{|c|}{ Data Report } \\
\hline & 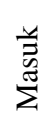 & 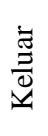 & 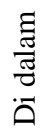 & 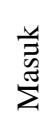 & 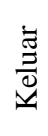 & $\begin{array}{l}\frac{\tilde{J}}{\tilde{J}} \\
\overline{0} \\
\end{array}$ \\
\hline 1 & 8 & 1 & 7 & 8 & 1 & 7 \\
\hline 2 & 13 & 1 & 12 & 13 & 1 & 12 \\
\hline 3 & 22 & 2 & 20 & 22 & 2 & 20 \\
\hline 4 & 29 & 3 & 26 & 29 & 3 & 26 \\
\hline 5 & 38 & 4 & 34 & 38 & 4 & 34 \\
\hline 6 & 49 & 8 & 41 & 49 & 8 & 41 \\
\hline 7 & 56 & 8 & 48 & 56 & 8 & 48 \\
\hline 8 & 61 & 10 & 51 & 61 & 10 & 51 \\
\hline 9 & 66 & 10 & 56 & 66 & 10 & 56 \\
\hline 10 & 66 & 15 & 51 & 66 & 15 & 51 \\
\hline 11 & 66 & 21 & 45 & 66 & 21 & 45 \\
\hline 12 & 67 & 26 & 41 & 67 & 26 & 41 \\
\hline 13 & 67 & 33 & 34 & 67 & 33 & 34 \\
\hline 14 & 67 & 42 & 25 & 67 & 42 & 25 \\
\hline 15 & 67 & 52 & 15 & 67 & 52 & 15 \\
\hline 16 & 68 & 57 & 11 & 68 & 57 & 11 \\
\hline 17 & 68 & 65 & 3 & 68 & 65 & 3 \\
\hline 18 & 68 & 68 & 0 & 68 & 68 & 0 \\
\hline
\end{tabular}
tersimpan pada file data reporting.
Tabel 4. Pengujian ketepatan data reporting

Contoh hasil pengujian data reporting tersaji pada Gambar 9 dan Gambar 10.

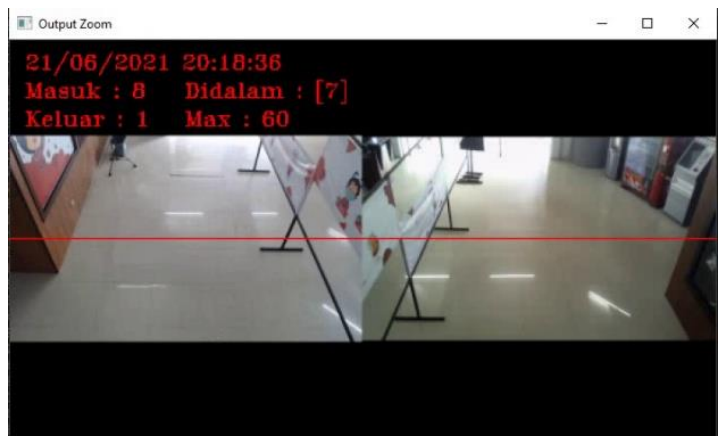

Gambar 9. Hasil penghitungan pada aplikasi

Sebagai contoh pembahasan dari hasil Tabel 4 terkait dengan pengujian ketepatan data reporting dapat dilihat pada percobaan pertama melalui perbandingan antara hasil penghitungan aplikasi dan hasil data yang telah tersimpan pada file .csv sebagai data reporting. Hasil perbandingannya antara jumlah pengunjung yang masuk, keluar dan yang masih berada dalam ruangan mempunyai kesamaan data $100 \%$ sebagaimana tampak pada Gambar 10. 


\begin{tabular}{|r|r|r|r|}
\hline Waktu & Masuk & Keluar & Di Dalam \\
\hline $8: 18: 36 \mathrm{PM}$ & 1 & & 1 \\
& 2 & & \\
\hline & 3 & & \\
\hline & 4 & & \\
\hline & 5 & & \\
\hline & 7 & & \\
\hline & 8 & & \\
\hline
\end{tabular}

Gambar 10. Hasil penghitungan pada file data reporting

\section{KESIMPULAN DAN SARAN}

Berdasarkan hasil dari pengujian yang dilakukan pada penelitian ini didapatkan beberapa poin kesimpulan sebagai berikut:

1. Hasil aplikasi dalam mendeteksi object orang atau pengunjung satu per satu yang dikondisikan berjalan normal akurasinya $100 \%$, berjalan cepat akurasi deteksinya $90 \%$ sedangkan pada kondisi berlari akurasinya hanya sebesar $50 \%$ obyek orang yang terdeteksi.

2. Akurasi aplikasi penghitung jumlah pengunjung ketika diterapkan dengan kondisi nyata dengan komputasi banyak orang pada pintu masuk restoran mendapatkan nilai akurasi sebesar $86 \%$ dalam menghitung pengunjung masuk, akurasi $66 \%$ dalam menghitung pengunjung keluar, dan $79 \%$ dalam menghitung jumlah pengunjung yang masih berada di dalam ruangan. Perbedaan persentasi akurasi yang terjadi antara kesimpulan 1 dan kesimpulan 2 ini dikarenakan, pertama perbedaan komputasi jumlah banyaknya orang yang dideteksi, yang kedua pada kesimpulan pertama menggunakan kamera kabel dengan panjangnya 1,5 meter yang langsung terkoneksi ke komputer sedangkan kamera yang digunakan pada kesimpulan 2 menggunakan IP Camera wireless dengan jarak sekitar 5 meter. Dikarenakan menggunakan kamera IP wireless itulah transmisi data dalam bentuk video terdapat delay yang mana besar kecilnya delay dipengaruhi oleh kecepatan koneksi dan besarnya bandwidth jaringan wifi setempat.

3. Notifikasi berupa bunyi buzzer sudah berjalan sesuai dengan alur aplikasi ketika mengalami jumlah pengunjung yang berada di dalam ruangan melebihi batas maksimal yang sudah ditentukan.

4. Perbandingan antara nilai data hasil penghitungan pada aplikasi sudah sama dengan nilai data yang tersimpan pada file data reposting (.csv).

Untuk penelitian selanjutnya terdapat beberapa saran yang dapat diimplementasikan untuk pengembangan aplikasi ini:

1. Meningkatkan efisiensi reporting dengan menjadikan data pada file .csv menjadi lebih sedikit yang mencatat data setiap menit atau jam, tidak mencatat setiap frame seperti saat ini.
2. Meningkatkan tampilan GUI (Graphical User Interface) agar lebih interaktif dan mudah dipahami oleh pengguna.

3. Posisi pemasangan kamera akan lebih maksimal ketika berada di ketinggian 3 meter sampai 4 meter dari lantai dengan sudut kamera $45^{\circ}$ menghadap ke bawah, sehingga POV (Point Of View) kamera menjadi lebih luas.

4. Mengintegrasikan sistem penghitungan jumlah pengunjung dengan sistem pendeteksi suhu dan sistem pendeteksi jarak antar pengunjung (physichal distancing) agar menjadi suatu sistem yang kompleks dan lebih efektif.

\section{Ucapan Terimakasih}

Tim mengucapkan terima kasih kepada Universitas Dinamika atas dukungan terhadap atas terbitnya Jurnal (JoTI). Selain itu tim mengucapkan terima kasih dan penghargaan diberikan kepada editor yang telah membahas makalah ini.

\section{DAFTAR PUSTAKA}

[1] Susilo, Adityo., 2020, Coronavirus Disease 2019: Tinjauan Literatur Terkini, Jurnal Penyakit Dalam Indonesia, vol 7, hal 45-67. DOI: 10.7454/jpdi.v7i1.415.

[2] Handayani, Diah., Rendra Hadi, Dwi., Isbaniah, Fathiyah., Burhan, Erlina., Agustin, Heidy., 2020, Penyakit Virus Corona 2019, Jurnal Respirologi Indonesia, vol 40, hal 119-129.

[3] Alkautsar, Ahmad., 2021, Hubungan Penyakit Komorbid Dengan Tingkat Keparahan Pasien Covid-19, Jurnal Medika Hutama, vol 3, hal 14881494.

[4] Muhammad Ali Satria, Raden., Varia Tutupoho, Resty., Chalidyanto, Djazuly., 2020, Analisis Faktor Risiko Kematian Dengan Penyakit Komorbid COVID-19, Jurnal Keperawatan Silampari, vol 4, hal 48-55. DOI: 10.31539/jks.v4i1.1587.

[5] Parwanto, Edy., 2021, Virus Corona (SARS-Cov2) Penyebab COVID-19 Kini Telah Bermutasi, Jurnal Biomedika dan Kesehatan, vol 3, hal 47-49. DOI: 10.18051/JBiomedKes.2021.v4.47-49.

[6] Hanifa, Nurul., Wajuba Perdini Fisabilillah, Ladi., 2021, Peran Dan Kebijakan Pemerintah Indonesia Di Masa Pandemi COVID-19, Welfare: Jurnal Ilmu Ekonomi, vol 2, hal 9-19.

[7] Wiryawan, I Wayan., 2020, Kebijakan Pemerintah Dalam Penanganan Pandemi Virus Corona Disease 2019 (COVID-19) Di Indonesia, Prosiding Webinar Nasional Universitas Mahasaraswati Denpasar, hal 179-188.

[8] Firmansyah, Yudi., Kardina, Fani., 2020, Pengaruh New Normal Ditengah Pandemi Covid-19 Terhadap Pengelolahan Sekolah Dan Peserta Didik, Jurnal Buana Ilmu, vol 4, hal 99-112. DOI: 10.36805/bi.v4i2.1107.

[9] Muhyiddin, 2020, Covid-19, New Normal dan Perencanaan Pembangunan di Indonesia, The 
Indonesian Journal of Development Planning, vol 4, hal 240-252.

[10] Suci Amelia, Decha., Suwarni, Linda., Selviana., Mawardi., 2020, Kesiapan Rumah Makan di Era New Normal, Jurnal Ilmu Kesehatan Masyarakat, vol 4, hal 216-221. DOI: 10.33221/jikm.v9i04.769.

[11] Ezizwita., Sukma, Tri., 2021, Dampak Pandemi Covid-19 Terhadap Bisnis Kuliner dan Strategi Beradaptasi di Era New Normal, Jurnal Ekonomi dan Bisnis Dharma Andalas, vol 23, hal 51-63.

[12] Sik-Ho Tsang., 2018, https://towardsdatascience.com. Retrieved 02 20, 2021, from

https://towardsdatascience.com/review-ssd-singleshot-detector-object-detection-851a94607d11.

[13] Chen Z., K. R., 2019, Real Time Object Detection, Tracking, and Distance and Motion Estimation based on Deep Learning: Application to Smart Mobility, Proceedings of the 2019 Eighth International Conference on Emerging Security Technologies (EST), hal 1-6.

[14] R. G. Fajri, I. S., 2021, Perancangan Program Pendeteksi Dan Pengklasifikasi Jenis Kendaraan Dengan Metode Convolutional Neural Network (CNN) Deep Learning, Ransient: Jurnal Ilmiah Teknik Elektro, vol 1, hal 97-106. DOI: 10.14710/ transient.1. 1.\%25p.

[15] Kusno Prasetya, A. A., 2020, Implementation of Tensorflow in the CCTV-Based People Counter Application at PT Matahari Department Store, Tbk, IAIC International Conferences, vol 3, hal 38-44.

[16] S. A. Sanchez,. et all., 2019, A Review: Comparison of Performance Metrics of Pretrained Models for Object Detection Using the TensorFlow Framework. IOP Conf. Series: Materials Science and Engineering 844 (2020) 012024, DOI: 10.1088/1757-899X/844/1/012024.

[17] Sukusvieri, A., 2020, Sistem keamanan menggunakan kamera berbasis wajah dengan metode Single Shot Detector (SSD). Tugas Akhir. Fakultas Teknologi Informatika. Universitas Dinamika. Surabaya.

[18] Rifai, A., 2020, Analisis perhitungan bibit ikan gurame menggunakan webcam dengan metode YOLO (You Only Look Once). Tugas Akhir. Fakultas Teknologi Informatika. Universitas Dinamika. Surabaya.

[19] Hidayatulloh, M., S., 2021, Sistem pengenalan wajah menggunakan metode YOLO (You Only Look Once). Tugas Akhir. Fakultas Teknologi Informatika. Universitas Dinamika. Surabaya.

[20] Zhang K,. et all., 2005, Assessment of humanlocomotion by using an insole measurement system and artificial neural netwrks. ELSEVIER: Journal of Biomechanics 38 (2005) 2276-2287. USA. 